\title{
Detection of virus particles by electron microscopy with polyacrylamide hydrogel
}

\author{
HILARY J WHITBY AND FG RODGERS \\ From the Public Health Laboratory, University Hospital, Queen's Medical Centre, Nottingham NG7 2UH, \\ UK
}

SUMMARY The use of lyphogel to concentrate the number of virus particles in specimens for electron microscopic examination was studied in parallel with ultracentrifugation. One hundred faecal and urine samples were compared. Both methods had a similar sensitivity. Lyphogel was economical, simple, and rapid in use; in contrast to ultracentrifugation, it required relatively little material. The procedure could be done within a safety cabinet, and virus particles were morphologically undamaged by the process.

Viruses excreted in the course of enteric infections often do not grow in cell culture, nor, without specific antiserum, are immunofluorescent methods satisfactory. For such viruses, electron microscopy is an effective approach. It can detect any virus group present by its morphological appearance. The drawback is a relative insensitivity. Because of this, techniques for concentrating virus particles before examination have been studied. For virusinduced gastroenteritis, ultracentrifugation of faecal extracts has been widely practised. ${ }^{12}$ Immune electron microscopy, ${ }^{3}$ density gradient formation, ${ }^{4}$ and ammonium sulphate precipitation ${ }^{5}$ have also been used successfully, leading to the implication of several species of viruses in this syndrome. ${ }^{6}$ Similarly, papova and cytomegaloviruses have been associated with prolonged infection in immunosuppressed renal transplant patients and in congenital abnormalities. ${ }^{7} 8$

This report compares the ability of lyphogel*, a selectively absorbent polyacrylamide hydrogel, to concentrate virus particles in faecal extracts and urine samples before electron microscopy with the alternative method of ultracentrifugation.

\section{Material and methods}

Of 100 specimens examined by negative stain electron microscopy for virus particles, 72 were stool samples from patients with infantile gastroenteritis and 28 were urine samples from patients with renal

*Gelman Hawksley Limited

Received for publication 9 October 1979 transplants or suspected congenital abnormalities. Ten per cent faecal suspensions in Hanks' balanced salt solution (HBSS) were prepared by vortex mixing on an MSE whirlimixer and then clarified by centrifugation at $4000 \mathrm{rpm}$ for 20 minutes at $+4^{\circ} \mathrm{C}$ in an MSE Coolspin centrifuge. Of the 100 specimens, both lyphogel concentration and ultracentrifugation were used on 81 , but for 18 urine samples and one stool extract from neonates only lyphogel could be used due to shortage of material.

GRID PREPARATION: LYPHOGEL METHOD Clarified faecal suspension or uncentrifuged urine $(0.55 \mathrm{ml})$ was added to a serum vial containing $0.1 \mathrm{~g}$ of lyphogel and left for a minimum of 4 hours at room temperature to allow fluid absorption to occur. The residual fluid was removed by pipette and applied to a formvar-carbon-coated 400 mesh electron microscope grid. Excess was drained off with filter paper, and grids were washed with 1-2 drops distilled water, blotted, and negatively stained with $3 \%$ phosphotungstic acid pH 6.5 (PTA). After inactivation of infectious material on the grids by exposure to short-wave ultraviolet irradiation for 5 minutes per side, each grid was examined for a minimum of 20 minutes in an AEI Corinth 500 or Jeol $100 \mathrm{C}$ electron microscope.

GRID PREPARATION：ULTRACENTRIFUGATION METHOD

Approximately $5 \mathrm{ml}$ of each clarified faecal suspension was centrifuged at $8000 \mathrm{rpm}$ for 45 minutes, and the supernates from these, and the urine samples, were centrifuged at $40000 \mathrm{rpm}$ for 1 hour at $+4^{\circ} \mathrm{C}$ in a Beckman L5-65 ultracentrifuge. The 
pellets were resuspended in 2 drops distilled water, mixed with an equal volume of $3 \%$ PTA, and added to electron microscope grids for examination.

\section{SENSITIVITY}

The comparison included stool specimens positive for rotavirus, adenovirus, coronavirus, or caliciviruses. Samples were diluted until virus was just detectable by direct examination of clarified suspensions. These were then concentrated from $5 \mathrm{ml}$ and $0.55 \mathrm{ml}$ samples by ultracentrifugation and from $0.55 \mathrm{ml}$ volumes by lyphogel. The concentrates from each of the three methods were diluted $1: 10,1: 50$, $1: 100$, and 1:200 in distilled water and were prepared by negative staining for electron microscopy.

\section{Results}

Virus particles were seen with equal ease in samples concentrated by either method (Table 1). In the lyphogel preparations, however, the amount of background debris on grids was small, facilitating the recognition of virus particles (Figure).

Table $1 \quad 81$ stool and urine specimens examined in parallel*

\begin{tabular}{lllll}
\hline Virus & \multicolumn{2}{l}{ Positive } & & \\
\cline { 2 - 5 } & $\begin{array}{l}\text { By both } \\
\text { methods }\end{array}$ & $\begin{array}{l}\text { By lyphogel } \\
\text { only }\end{array}$ & $\begin{array}{l}\text { By ultracentrifugation } \\
\text { only }\end{array}$ & Total \\
\hline Rotavirus & 25 & 1 & 0 & 26 \\
Adenovirus & 5 & 1 & 0 & 6 \\
Coronavirus & 9 & 0 & 0 & 9 \\
Calicivirus & 1 & 0 & 0 & 6 \\
SRV† & 5 & 0 & 1 & 48 \\
Total & 45 & 2 & 1 & 1 \\
\hline
\end{tabular}

* 33 were negative by both methods.

†Small, round, isometric virus particles, approximately $25 \mathrm{~nm}$ in diameter.
Viruses in faecal extracts concentrated by lyphogel: (a) smooth rotavirus particle; (b) single adenovirus; (c) coronavirus; (d) group of antibody-coated small round virus particles $(S R V)$. All negatively stained with $3 \%$ PTA $\times 150000$. 
The ability to detect viruses in stool extracts concentrated by either method was similar if 10 times the volume used for lyphogel treatment was ultracentrifuged. When equal volumes of extract were used in both methods, the lyphogel technique was more sensitive (Table 2). In addition, washed extracts of the lyphogel used to concentrate virus positive specimens were negative for viruses by electron microscopy, indicating that virus particles were not adsorbed to the hydrogel, and therefore did not affect the sensitivity of the test.

Table 2 Sensitivity of concentration method for detection of viruses by electron microscopy

\begin{tabular}{lccc}
\hline Virus & $\begin{array}{c}\text { Lyphogel } \\
(0.55 \mathrm{ml})\end{array}$ & \multicolumn{2}{c}{ Ultracentrifugation } \\
\cline { 3 - 4 } & & $0.55 \mathrm{ml}$ & $5 \mathrm{ml}$ \\
\hline Rotavirus & $100^{*}$ & $<10$ & 50 \\
Adenovirus & 50 & 10 & 50 \\
Coronavirus & 10 & $<10$ & 10 \\
Calicivirus & 100 & $<10$ & 100 \\
\hline
\end{tabular}

* Reciprocal of highest dilution showing virus particles.

Of the 18 urine and one stool specimens from neonates concentrated by lyphogel, only one urine contained small round virus (SRV) particles. In later studies, 135 specimens have been concentrated for electron microscopy by lyphogel only, with no apparent deterioration of results.

\section{Discussion}

The lyphogel technique for concentrating viruses in specimens for electron microscopy is simple, reliable, and comparatively safe. An ultracentrifuge is not required. When large numbers of faecal extracts have to be examined, the use of lyphogel is quicker and less laborious. It also leaves the centrifuge free for other procedures. Its cost, at approximately $3 p$ per test, compares favourably with that of ultracentrifugation. The concentration factor was similar for both, but, with the smaller volumes needed for lyphogel, valuable material could be retained, such as specimens from neonates.

With lyphogel, specimens can be prepared individually as they are received in the laboratory or accumulated till the end of the day, then treated and left overnight at $+4^{\circ} \mathrm{C}$ to concentrate, so that they can be ready for immediate examination next morning with reports available by mid-day.

Lyphogel has been used to concentrate hepatitis B surface antigen (HBsAg) in patients' sera to improve the sensitivity of serological tests. ${ }^{9}$ However, numerous small lipoprotein-like molecules resembling $\mathbf{H B s A g}{ }^{10}$ were observed in sera examined by electron microscopy after lyphogel concentration, and these made interpretation of results, in this instance, difficult. In aqueous extracts, however, due to the non-selectivity of lyphogel for low molecular weight substances, the $\mathrm{pH}$ and molarity of the concentrates remained unchanged during the fluid absorption process so that virus particles were not affected by changing ionic concentrations. Absorption of water, salts, and small molecules of less than 20 mega-daltons did not denature proteins and had no detrimental effect on antibody-coated virus particles. Without the need for ultracentrifugation, the lyphogel method maintained the integrity of virus particles. Capsids were free from distortion, disruption, or removal of the outer projections from, for example, coronaviruses. These effects are known to occur in ultracentrifugation. In addition, the use of lyphogel to concentrate viruses facilitates the examination of pathogens under safe conditions by reducing the amount of specimen handling required, and it can all be done in a safety cabinet.

Thanks are due to Mrs $\mathbf{J}$ Casson for help in preparing the electron micrographs and to $\mathrm{Dr} A D$ Macrae for useful discussion.

\section{References}

${ }^{1}$ Flewett TH, Bryden AS, Davies H. Diagnostic electron microscopy of faeces. I. The viral flora of the faeces as seen by electron microscopy. II. Acute gastroenteritis associated with reovirus-like particles. J Clin Pathol 1974;27:603-14.

${ }^{2}$ Bishop RF, Davidson GP, Holmes IH, Ruck BJ. Detection of a new virus by electron microscopy of faecal extracts from children with acute gastroenteritis. Lancet 1974;1:149-51.

${ }^{3}$ Kapikian AZ, Wyatt RG, Dolin R, Thornhill TS, Kalica AR, Chanock RM. Visualization by immune electron microscopy of a $27-\mathrm{nm}$ particle associated with acute infectious nonbacterial gastroenteritis. J Virol 1972;10:1075-81.

${ }^{4}$ Kapikian AZ, Gerin JL, Wyatt RG, Thornhill TS, Chanock RM. Density in cesium chloride of the $27 \mathrm{~nm}$ '8FIIa' particle associated with acute infectious non-bacterial gastroenteritis; determination by ultracentrifugation and immune electron microscopy. Proc Soc Exp Biol Med 1973;142:874-7.

${ }^{5}$ Caul EO, Ashley CR, Egglestone SI. An improved method for the routine identification of faecal viruses using ammonium sulphate precipitation. FEMS Microbiol Lett 1978;4:1-4.

${ }^{6}$ Madeley CR. Viruses in the stools. J Clin Pathol 1979;32:1-10.

${ }^{7}$ Gardner SD. The new human papovaviruses: their nature and significance. In: Waterson AP, ed. Recent Advances in Clinical Virology-1. Edinburgh and London: Churchill Livingstone 1977:93-115. 
${ }^{8}$ Stern H. Cytomegalovirus vaccine: justification and problems. In: Waterson AP, ed. Recent Advances in Clinical Virology-1. Edinburgh and London: Churchill Livingstone, 1977:117-34.

${ }^{9}$ Ashcavai M, Peters RL. Hepatitis-associated antigen: improved sensitivity in detection. Amer J Clin Pathol $1971 ; 55: 262-8$.

${ }^{10}$ Solaas MH. Comparison of small hepatitis B surface antigen particles and human serum low density lipoprotein molecules by electron microscopy. Acta Pathol Microbiol Scand [B] 1978;86:125-9.

Requests for reprints to: Dr FG Rodgers, Public Health Laboratory, University Hospital, Queen's Medical Centre, Nottingham NG7 2UH, UK.

\section{The April 1979 Issue}

\section{THE APRIL 1979 ISSUE CONTAINS THE FOLLOWING PAPERS}

The examination of ebryonic and fetal material in diagnostic histopathology laboratories C BERRY

Variations in the ultrastructure of human nasal cilia including abnormalities found in retinitis pigmentosa B FOX, TB BULL, AND GB ARDEN

Histochemical diagnosis of Hirschsprung's disease and a comparison of the histochemical and biochemical activity of acetylcholinesterase in rectal mucosal biopsies WJA PATRICK, GTN BESLEY, AND II SMITH

Histopathological changes in the liver after allogeneic bone marrow transplantation JP SLOANE, MJG FARTHING, AND RL POWLES

Use of a histopathology data pool for epidemiological analysis JC MACARTNEY, TP ROLLASON, AND BW CODLING

Demonstration of carcinoembryonic antigen in human breast carcinomas by the immunoperoxidase technique ROSEMARY A WALKER

A quantitative study of the influence of fixation on immunoperoxidase staining of rectal mucosal plasma cells J PIRIS AND ND THOMAS

Direct immunofluorescence of skin using formalinfixed paraffin-embedded sections SL MERA, EW YOUNG, AND JWB BRADFIELD

A serum-dependent defect of neutrophil function in chronic mucocutaneous candidiasis SM WALKER AND SJ URBANIAK

An assessment of red cell deformability using a simple filtration method MM DRUMMOND, GDO LOWE, JJF BELCH, JC BARBENEL, AND CD FORBES
Quantitation of oestrogen receptors: use of solidphase antisteroid antibodies to quantify binding sites and determination of dissociation constant S RAAM AND JL COHEN

Age- and sex-related reference ranges for eight plasma constituents derived from randomly selected adults in a Scottish new town MARY D GARDNER AND R SCOTT

Grouping of beta-haemolytic streptococci by agglutination CSF EASMON, SUZANNE EM COX, AND ALISON HOWARD

Immunoassay of serum conjugates of cholic acid in cystic fibrosis GP DAVIDSON, MARY COREY, FREDA MORAD-HASSELL, JUDITH M SONDHEIMER, D CROZIER, AND GG FORSTNER

Synergistic haemolysis test for presumptive identification and differentiation of Clostridiumperfringens, $C$. bifermentans, $C$. sordellii, and $C$. paraperfringens SM GUBASH

Epidemiological study of klebsiella infection in the special care baby unit of a London hospital EVE RISER, P NOONE, AND FRANCES M HOWARD

An experimental model for ascending acute pyelonephritis caused by Escherichia coli or proteus in rats P LARSSON, B KAIJSER, I MATTSBY BALTZER, AND S OLLING

Letters to the Editor

Book reviews

Copies are still available and may be obtained from the PUBLISHING MANAGER, BRITISH MEDICAL ASSOCIATION, TAVISTOCK SQUARE, LONDON WC1H 9JR, price $£ 3.00$, including postage 